\title{
DMP1 Gene
}

National Cancer Institute

\section{Source}

National Cancer Institute. DMP1 Gene. NCI Thesaurus. Code C95575.

This gene plays a role in osteoblast differentiation and ossification. 